\title{
Accessories Make the Outfit: Accessory Chromosomes and Other Dispensable DNA Regions in Plant-Pathogenic Fungi
}

\author{
Stefania Bertazzoni, ${ }^{1}$ Angela H. Williams, ${ }^{1}$ Darcy A. Jones, ${ }^{1}$ Robert A. Syme, ${ }^{1}$ Kar-Chun Tan, ${ }^{1}$ and \\ James K. Hane ${ }^{1,2, \dagger}$ \\ ${ }^{1}$ Centre for Crop \& Disease Management, Curtin University, Perth, Western Australia, Australia; and ${ }^{2}$ Curtin Institute for \\ Computation, Curtin University, Perth, Western Australia, Australia
}

Accepted 3 March 2018.

\begin{abstract}
Fungal pathogen genomes can often be divided into core and accessory regions. Accessory regions ARs) may be comprised of either ARs (within core chromosomes (CCs) or wholly dispensable (accessory) chromosomes (ACs). Fungal ACs and ARs typically accumulate mutations and structural rearrangements more rapidly over time than CCs and many harbor genes relevant to host-pathogen interactions. These regions are of particular interest in plant pathology and include host-specific virulence factors and secondary metabolite synthesis gene clusters. This review outlines known ACs and ARs in fungal genomes, methods used for their detection, their common properties that differentiate them from the core genome, and what is currently known of their various roles in pathogenicity. Reports on the evolutionary processes generating and shaping $A C$ and AR compartments are discussed, including repeat induced point mutation and breakage fusion bridge cycles. Previously ACs have been studied extensively within key genera, including Fusarium, Zymoseptoria, and Alternaria, but are growing in frequency of observation and perceived importance across a wider range of fungal species. Recent advances in sequencing technologies permit affordable genome assembly and resequencing of populations that will facilitate further discovery and routine screening of ACs.
\end{abstract}

All organisms require the maintenance of a stable genome that encodes essential functions for life. In some cases, such as for several fungal pathogen species, certain conditions such as environmental stress, continuously evolving host defenses, or adoption of resistant cultivars may also promote genome plasticity. The concept of a 'core' genome that is common to all isolates encoding all genes necessary for survival under normal growth conditions has emerged and is distinguished from the 'accessory' genome (Ma et al. 2010; Raffaele and Kamoun 2012; Syme et al. 2013; Vanheule et al. 2016). Accessory genetic elements are well-studied in bacterial genomes, which may contain plasmids that harbor pathogenicity islands (Jackson et al.

${ }^{\dagger}$ Corresponding author: J. K. Hane; E-mail: James.Hane@curtin.edu.au

Funding: This study was supported by the Centre for Crop and Disease Management, a joint initiative of Curtin University and the Grains Research and Development Corporation research grant CUR00023.

@ 2018 The American Phytopathological Society
2011), and in plant genomes, which may contain supernumerary 'B' chromosomes (Jones et al. 2008; Makunin et al. 2014). The accessory genomes of fungi may be comprised of either segments of core chromosomes (CCs) that may be partially lost (accessory regions [Ars]) or wholly dispensable (accessory) chromosomes (ACs). ACs have been described by several terms (Covert 1998), (conditionally) dispensable chromosomes, lineagespecific chromosomes, supernumerary chromosomes, and B chromosomes. The term 'minichromosome' also describes a short chromosome (i.e., <2 Mbp) that may (or may not) be an AC.

Known fungal ACs exhibit one or more common properties that differentiate them from CCs. An AC may confer an advantage under certain conditions, for example, ACs of plant pathogens may encode genes that determine an advantageous outcome during interaction with a host, including effectors and metabolic gene clusters (MGCs) (Table 1). Fungal ACs are often meiotically unstable and may be inherited in a nonmendelian manner (Covert 1998). Some ACs have also been observed to transfer from a competent to a deficient strain of the same species (Akagi et al. 2009; He et al. 1998; Ma et al. 2010; Manners and He 2011; Vlaardingerbroek et al. 2016b). Compared with CCs, ACs typically have lower gene density and are enriched in transposable elements (TEs) and other repeats (de Jonge et al. 2013; Galazka and Freitag 2014; Hatta et al. 2002; Klosterman et al. 2011; Ma et al. 2010; Vanheule et al. 2016; Williams et al. 2016). They are typically small ( $<2 \mathrm{Mbp})$, low in number, make up a small proportion of the total genome content, and encode fewer 'housekeeping' genes than CCs (Chuma et al. 2011; Goodwin et al. 2011; Jones et al. 1998; Luo et al. 2007; O'Connell et al. 2012; Talbot et al. 1993; Zolan 1995). Their reduced gene content suggests that there may be lowered selection pressure on ACs, which is supported by increased observations of transposon and other repetitive sequence content, single-nucleotide polymorphisms and structural mutations in ACs compared with CCs (Hane et al. 2011; Tsuge et al. 2016; Williams et al. 2016). The activity of fungal-specific genome mutagenesis mechanisms such as repeat induced point mutation (RIP) (Hane et al. 2015) and increased rates of intrachromosomal recombination (resulting in mesosynteny) (Hane et al. 2011) are likely to have heavily influenced the evolution of repeat-rich ACs. Large sections of chromosomes may be partially lost (ARs) and may have similar properties to ACs.

Supporting evidence for the presence of ARs and ACs varies widely in type and reliability. Early studies used karyotype profiling - sometimes assigned to known genetic linkage 
groups, genetic maps, or physical maps-which can indicate chromosome length polymorphism (CLP), copy number variation, and presence/absence variation (PAV) (Zolan 1995). Whole-genome sequencing has been complementary to karyotyping (Vlaardingerbroek et al. 2016a and b) but has also been used independently to infer ACs. For species in which reference chromosomes have been established, resequencing of multiple isolates has been used to determine PAV versus reference chromosomes (McDonald et al. 2016). Purely bioinformatic methods can also infer ACs or ARs in even highly fragmented genome assemblies, either by subtraction of highly conserved core genome matches (Williams et al. 2016), by prediction of AC-like properties (Ohm et al. 2012), or through observation of both macro- and mesosynteny between

Table 1. Summary of known fungal accessory chromosomes (ACs), accessory regions (ARs), and their properties ${ }^{\mathrm{a}}$

\begin{tabular}{|c|c|c|c|c|c|c|c|}
\hline Taxonomy & Species & $\begin{array}{l}\text { Strain/isolate/ } \\
\text { biotype }\end{array}$ & $\begin{array}{l}\text { ACs (number, } \\
\text { length, or } \\
\text { sequence IDs) }\end{array}$ & $\begin{array}{l}\text { Function/virulence } \\
\text { factors }\end{array}$ & $\begin{array}{l}\text { Pathogenicity } \\
\text { phenotype } \\
\text { and gene } \\
\text { content }\end{array}$ & Evidence type & References \\
\hline $\begin{array}{l}\text { Dothideomycetes } \\
\text { Botryosphaeriales }\end{array}$ & $\begin{array}{l}\text { Macrophomina } \\
\text { phaseolina }\end{array}$ & & $\begin{array}{l}0 \text { to } 6 \mathrm{ACs}:(785 \mathrm{~kb} \\
\text { to } 2 \mathrm{Mb})\end{array}$ & Unknown & Unknown & Electrophoretic karyotype & Jones et al. 1998 \\
\hline $\begin{array}{l}\text { Dothideomycetes } \\
\text { Capnodiales }\end{array}$ & $\begin{array}{l}\text { Zymoseptoria } \\
\text { ardabilae }\end{array}$ & ST04IR_1.1.1 & $4 \mathrm{ACs}$ & Unknown & Unknown & In silico read mapping & $\begin{array}{l}\text { Kellner et al. 2014; } \\
\quad \text { Stukenbrock et al. } 2012\end{array}$ \\
\hline $\begin{array}{l}\text { Dothideomycetes } \\
\text { Capnodiales }\end{array}$ & $\begin{array}{l}\text { Zymoseptoria } \\
\text { psuedotritici }\end{array}$ & ST04IR_2.2.1 & $6 \mathrm{ACs}$ & Unknown & Unknown & In silico read mapping & $\begin{array}{l}\text { Kellner et al. 2014; } \\
\quad \text { Stukenbrock et al. } 2012\end{array}$ \\
\hline $\begin{array}{l}\text { Dothideomycetes } \\
\text { Capnodiales }\end{array}$ & $\begin{array}{l}\text { Zymoseptoria } \\
\text { tritici (syn. } \\
\text { Mycosphaerella } \\
\text { graminicola. } \\
\text { Septoria tritici) }\end{array}$ & IPO323 & $\begin{array}{l}8 \text { ACs: } 14 \text { to } 21 \\
(0.4 \text { to } 0.8 \mathrm{Mb})\end{array}$ & Unknown & Virulence (wheat) & $\begin{array}{l}\text { Sequence alignment; } \\
\text { electrophoretic } \\
\text { karyotype; in silico read } \\
\text { mapping }\end{array}$ & $\begin{array}{l}\text { Croll and McDonald 2012; } \\
\text { Goodwin et al. 2011; } \\
\text { McDonald et al. 2016; } \\
\text { Mehrabi et al., 2007; } \\
\text { Stewart et al. 2018; Ware } \\
\text { 2006; Wittenberg et al., } \\
\text { 2009 }\end{array}$ \\
\hline $\begin{array}{l}\text { Dothideomycetes } \\
\text { Capnodiales }\end{array}$ & $\begin{array}{l}\text { Pseudocercospora } \\
\text { (syn. } \\
\text { Mycosphaerella) } \\
\text { fijiensis }\end{array}$ & CIRAD86 & Scaffolds 11 to 26 & Unknown & Unknown & $\begin{array}{l}\text { Prediction-sequence } \\
\text { properties; Comparative } \\
\text { genomics }\end{array}$ & $\begin{array}{l}\text { Arango Isaza et al. 2016; } \\
\text { Ohm et al. } 2012\end{array}$ \\
\hline $\begin{array}{l}\text { Dothideomycetes } \\
\text { Pleosporales }\end{array}$ & $\begin{array}{l}\text { Alternaria } \\
\text { alternata f. sp. } \\
\text { citri (tangerine } \\
\text { pathotype) }\end{array}$ & SH20 & $<2 \mathrm{Mb}$ & $\begin{array}{l}\text { ACT-toxin biosynthesis } \\
\text { cluster }\end{array}$ & $\begin{array}{l}\text { Virulence } \\
\text { (tangerine) }\end{array}$ & Electrophoretic karyotype & $\begin{array}{l}\text { Akamatsu et al. 1999; } \\
\text { Miyamoto et al. } 2008\end{array}$ \\
\hline $\begin{array}{l}\text { Dothideomycetes } \\
\text { Pleosporales }\end{array}$ & $\begin{array}{l}\text { Alternaria } \\
\text { alternata } \mathrm{f} \text {. sp. } \\
\text { citri (rough } \\
\text { lemon } \\
\text { pathotype) }\end{array}$ & $\mathrm{HC} 1$ & $<1.5 \mathrm{Mb}$ & $\begin{array}{l}\text { ACR-toxin biosynthesis } \\
\text { cluster }\end{array}$ & Virulence (lemon) & Electrophoretic karyotype & $\begin{array}{l}\text { Akamatsu et al. 1999; } \\
\text { Masunaka et al. } 2005\end{array}$ \\
\hline $\begin{array}{l}\text { Dothideomycetes } \\
\text { Pleosporales }\end{array}$ & $\begin{array}{l}\text { Alternaria } \\
\text { alternata f. sp. } \\
\text { fragariae }\end{array}$ & NAF8 & $1.0 \mathrm{Mb}$ & $\begin{array}{l}\text { AF-toxin biosynthesis } \\
\text { cluster }\end{array}$ & $\begin{array}{l}\text { Virulence } \\
\quad \text { (strawberry) }\end{array}$ & Electrophoretic karyotype & $\begin{array}{l}\text { Akamatsu et al. 1999; } \\
\text { Hatta et al. } 2002\end{array}$ \\
\hline $\begin{array}{l}\text { Dothideomycetes } \\
\text { Pleosporales }\end{array}$ & $\begin{array}{l}\text { Alternaria } \\
\text { alternata f. sp. } \\
\text { mali }\end{array}$ & IFO8984 & $<1.8 \mathrm{Mb}$ & $\begin{array}{l}\text { AM-toxin biosynthesis } \\
\text { cluster }\end{array}$ & Virulence (apple) & Electrophoretic karyotype & $\begin{array}{l}\text { Akagi et al. 2009; } \\
\text { Akamatsu et al. 1999; } \\
\text { Harimoto et al. 2007; } \\
\text { Johnson et al. 2000; } \\
\text { Taga et al. } 1999\end{array}$ \\
\hline $\begin{array}{l}\text { Dothideomycetes } \\
\text { Pleosporales }\end{array}$ & $\begin{array}{l}\text { Alternaria } \\
\text { arborescens } \\
\text { (syn. A. } \\
\text { alternata f. sp. } \\
\text { lycopersici) }\end{array}$ & $\begin{array}{l}\text { EGS 39-128 } \\
\text { As-27 }\end{array}$ & $1.0 \mathrm{Mb}$ & $\begin{array}{l}\text { AAL-toxin biosynthesis } \\
\text { cluster }\end{array}$ & Virulence (tomato) & Electrophoretic karyotype & $\begin{array}{l}\text { Akagi et al. 2009; } \\
\text { Akamatsu et al. 1999; } \\
\text { Hu et al. } 2012\end{array}$ \\
\hline $\begin{array}{l}\text { Dothideomycetes } \\
\text { Pleosporales }\end{array}$ & Alternaria gaisen & $\begin{array}{l}\text { O-276, ML10E, K-111, } \\
15 \text { A }\end{array}$ & $<2 \mathrm{Mb}$ to $4.1 \mathrm{Mb}$ & $\begin{array}{l}\text { AK-toxin biosynthesis } \\
\text { cluster }\end{array}$ & $\begin{array}{l}\text { Virulence (japanese } \\
\text { pear) }\end{array}$ & Electrophoretic karyotype & $\begin{array}{l}\text { Akamatsu et al. 1999; } \\
\text { Tanaka and Tsuge } 2000\end{array}$ \\
\hline $\begin{array}{l}\text { Dothideomycetes } \\
\text { Pleosporales }\end{array}$ & $\begin{array}{l}\text { Cochliobolus } \\
\text { carbonum }\end{array}$ & $\begin{array}{l}\text { SB111 (wt), 243-7 } \\
\text { (deletion strain) }\end{array}$ & $\begin{array}{l}3.5 \mathrm{Mb} \mathrm{AC}(1.4 \mathrm{Mb} \\
\text { deletion }) *\end{array}$ & $\begin{array}{l}\text { HC-toxin biosynthesis } \\
\text { cluster }\end{array}$ & $\begin{array}{l}\text { Virulence (maize, } \\
\text { genotype } \\
h m 1 / h m l \text { ) }\end{array}$ & Electrophoretic karyotype & Pitkin et al. 2000 \\
\hline $\begin{array}{l}\text { Dothideomycetes } \\
\text { Pleosporales }\end{array}$ & $\begin{array}{l}\text { Cochliobolus } \\
\text { heterostrophus }\end{array}$ & $\begin{array}{l}\text { Race } \mathrm{T} \text { isolates (e.g., } \\
\text { C5 parental strain: } \\
\text { B30.A3.R.45) }\end{array}$ & $\begin{array}{l}\sim 1.2 \mathrm{Mb} \text { ARs on } \mathrm{Chr} 6 \\
12, \text { and } 16\end{array}$ & $\begin{array}{l}\text { Toxl (T-toxin biosynthesis } \\
\text { cluster) on the AR, no } \\
\text { known virulence factors } \\
\text { map to Chr16 }\end{array}$ & $\begin{array}{l}\text { Virulence (corn, } \\
\text { Texas male sterile } \\
\text { cytoplasm) }\end{array}$ & $\begin{array}{l}\text { Electrophoretic karyotype; } \\
\text { RFLP }\end{array}$ & $\begin{array}{l}\text { Condon et al. 2013; } \\
\text { Kodama et al. 1999; Ohm } \\
\text { et al. 2012; Tzeng et al. } \\
1992\end{array}$ \\
\hline $\begin{array}{l}\text { Dothideomycetes } \\
\text { Pleosporales }\end{array}$ & $\begin{array}{l}\text { Leptosphaeria } \\
\text { maculans }\end{array}$ & $\mathrm{V} 23.1 .3 / \mathrm{JN} 3$ & $\begin{array}{l}\text { Scaffold SC22 } \\
(731.4 \mathrm{~kb}) \\
\sim 1 \mathrm{Mb} \mathrm{AC}\end{array}$ & $\begin{array}{l}\text { AvrLmll avirulence } \\
\text { effector }\end{array}$ & $\begin{array}{l}\text { Virulence (Brassica } \\
\text { rapa, cultivars } \\
\text { lacking } R l m 11 \text { ) }\end{array}$ & $\begin{array}{l}\text { Prediction—sequence } \\
\text { properties }\end{array}$ & $\begin{array}{l}\text { Balesdent et al. 2013; Ohm } \\
\text { et al. 2012; Plummer and } \\
\text { Howlett } 1995\end{array}$ \\
\hline $\begin{array}{l}\text { Dothideomycetes } \\
\text { Pleosporales }\end{array}$ & $\begin{array}{l}\text { Parastagonospora } \\
\text { nodorum }\end{array}$ & SN15 & $\begin{array}{l}\text { 1 AC: } \sim 300 \text { to } 700 \mathrm{~kb} \\
\text { Scaffold } 46^{\mathrm{b}}\end{array}$ & Unknown & $\begin{array}{l}\text { Reported AC } \\
\text { observed only in } \\
\text { wheat or barley } \\
\text { adapted strains }\end{array}$ & $\begin{array}{l}\text { Electrophoretic karyotype; } \\
\text { prediction- } \\
\text { sequence properties }\end{array}$ & $\begin{array}{l}\text { Ohm et al. 2012; Syme } \\
\text { et al. 2013; Zolan } 1995\end{array}$ \\
\hline $\begin{array}{l}\text { Dothideomycetes } \\
\text { Pleosporales }\end{array}$ & $\begin{array}{l}\text { Setosphaeria } \\
\text { turcica }\end{array}$ & Et28A & Scaffold 28 & Unknown & Unknown & $\begin{array}{l}\text { Prediction-bioinformatic } \\
\text { survey of sequence } \\
\text { properties }\end{array}$ & Ohm et al. 2012 \\
\hline \multirow[t]{4}{*}{$\begin{array}{l}\text { Leotiomycetes } \\
\text { Sclerotiniaceae }\end{array}$} & \multirow[t]{4}{*}{ Botrytis cinerea } & \multirow[t]{4}{*}{ B05.10 } & $\begin{array}{l}2 \text { minichromosomes, } \\
17 \text { and } 18\end{array}$ & Unknown & Unknown & Southern hybridization & \multirow[t]{4}{*}{ Van Kan et al. 2017} \\
\hline & & & 247 and $209 \mathrm{~kb}$ & Unknown & Unknown & Comparative genomics & \\
\hline & & & $\begin{array}{l}\text { Chr } 18 \text { lacking in strain } \\
\text { 09Bc11 }\end{array}$ & Unknown & Unknown & & \\
\hline & & & $\begin{array}{l}\text { Chr } 17 \text { nonuniform } \\
\text { coverage in strain } \\
\text { 09Bc11 }\end{array}$ & Unknown & Unknown & & \\
\hline \multirow[t]{3}{*}{$\begin{array}{c}\text { Sordariomycetes } \\
\text { Glomerellales }\end{array}$} & \multirow[t]{3}{*}{$\begin{array}{l}\text { Colletotrichum } \\
\text { gloeosporioides }\end{array}$} & Biotype A (common) & $1 \mathrm{AC}(\sim 2 \mathrm{Mb})$ & Unknown & $\begin{array}{l}\text { Virulence } \\
\text { (Stylosanthes } \\
\text { spp.) }\end{array}$ & $\begin{array}{l}\text { Electrophoretic karyotype; } \\
\text { RFLP }\end{array}$ & \multirow[t]{3}{*}{ He et al. 1998} \\
\hline & & Biotype B (rare) & $1 \mathrm{AC}(\sim 1.2 \mathrm{Mb})$ & Unknown & $\begin{array}{l}\text { Virulence } \\
\quad \text { (S. guianensis) }\end{array}$ & & \\
\hline & & Bx, UQ396 & & Unknown & $\begin{array}{l}\text { Chlorosis } \\
\quad(\text { S. scabra })\end{array}$ & & \\
\hline
\end{tabular}

(Continued on next page)

${ }^{\mathrm{a}} \mathrm{Chr}=$ chromosome; $\mathrm{RFLP}=$ restriction fragment length polymorphism; HGT = horizontal gene transfer; $\mathrm{PEP}=$ pea pathogenicity; $\mathrm{CC}=$ core chromosome; $\mathrm{FISH}=$ fluorescence in situ hybridization; $\mathrm{PCR}=$ polymerase chain reaction .

$\mathrm{b}$ Prediction based on bioinformatic survey of sequence properties. 
chromosomes of closely related genomes (Hane et al. 2011). The chromatin modification profile of a whole chromosome or large region has also been observed to correlate with ACs and may be an effective method of AC prediction (Galazka and Freitag 2014).

\section{KNOWN ACCESSORY CHROMOSOMES AND OTHER DISPENSABLE REGIONS}

Two of the best-studied species with ACs are from the Fusarium genus, F. solani (syn. Haematonectria hematococca)
(Coleman et al. 2009; Mehrabi et al. 2011; Miao et al. 1991) and F. oxysporum (Ma et al. 2010; Schmidt et al. 2013; Vanheule et al. 2016; Williams et al. 2016). These ACs are often meiotically unstable (Miao et al. 1991), gene sparse, and enriched for TEs and other repeats (Ma et al. 2010). F. solani possess at least three ACs (ATCC18098 chromosomes 14, 15, and 17), one of which encodes a pea pathogenicity (PEP) cluster required to detoxify the phytoalexin pisatin and confer virulence on pea (Temporini and VanEtten 2002). F. oxysporum is a species with several recognized formae speciales (pathovars) that are defined

Table 1. (Continued from previous page)

\begin{tabular}{|c|c|c|c|c|c|c|c|}
\hline Taxonomy & Species & $\begin{array}{c}\text { Strain/isolate/ } \\
\text { biotype }\end{array}$ & $\begin{array}{l}\text { ACs (number, } \\
\text { length, or } \\
\text { sequence IDs) }\end{array}$ & $\begin{array}{l}\text { Function/virulence } \\
\text { factors }\end{array}$ & $\begin{array}{l}\text { Pathogenicity } \\
\text { phenotype } \\
\text { and gene } \\
\text { content }\end{array}$ & Evidence type & References \\
\hline $\begin{array}{c}\text { Sordariomycetes } \\
\text { Glomerellales }\end{array}$ & $\begin{array}{l}\text { Colletotrichum } \\
\text { graminicola }\end{array}$ & $\begin{array}{l}\text { M1.001 (also known as } \\
\text { M2) }\end{array}$ & Chr 11-13 (<1 Mb) & Unknown & Unknown & $\begin{array}{l}\text { Prediction-comparative } \\
\text { genomics }\end{array}$ & O'Connell et al. 2012 \\
\hline $\begin{array}{c}\text { Sordariomycetes } \\
\text { Glomerellales }\end{array}$ & $\begin{array}{l}\text { Colletotrichum } \\
\text { higginsianum }\end{array}$ & IMI 349063 & Chr 11-12 (<1 Mb) & Unknown & Unknown & $\begin{array}{l}\text { Prediction-comparative } \\
\text { genomics }\end{array}$ & O'Connell et al. 2012 \\
\hline $\begin{array}{c}\text { Sordariomycetes } \\
\text { Glomerellales }\end{array}$ & $\begin{array}{l}\text { Colletotrichum } \\
\text { lindemuthianum }\end{array}$ & Race 0 , multiple isolates & 2 to $6 \mathrm{ACs}(<2.5 \mathrm{Mb})$ & Unknown & Unknown & $\begin{array}{l}\text { Electrophoretic karyotype; } \\
\text { Flow cytometry; } \\
\text { Southern hybridization }\end{array}$ & O'Sullivan et al. 1998 \\
\hline $\begin{array}{l}\text { Sordariomycetes } \\
\text { Hypocreales }\end{array}$ & $\begin{array}{l}\text { Fusarium } \\
\text { asiaticum }\end{array}$ & Not stated & Chr V (0.45 Mb) & Unknown & Unknown & $\begin{array}{l}\text { Prediction-epigenetic } \\
\text { profiling }\end{array}$ & Galazka and Freitag 2014 \\
\hline $\begin{array}{l}\text { Sordariomycetes } \\
\text { Hypocreales }\end{array}$ & Fusarium fujikuroi & Not stated & Chr XII (0.69 Mb) & Unknown & Unknown & $\begin{array}{l}\text { Prediction-epigenetic } \\
\text { profiling }\end{array}$ & Galazka and Freitag 2014 \\
\hline $\begin{array}{l}\text { Sordariomycetes } \\
\text { Hypocreales }\end{array}$ & $\begin{array}{l}\text { Fusarium } \\
\text { oxysporum f. sp. } \\
\text { ciceris \# }\end{array}$ & Foc-38-1 & Multiple scaffolds & Unknown & Unknown & $\begin{array}{l}\text { Prediction-bioinformatic } \\
\text { subtraction of core- } \\
\text { chromosome matches }\end{array}$ & Williams et al. 2016 \\
\hline \multirow[t]{3}{*}{$\begin{array}{l}\text { Sordariomycetes } \\
\text { Hypocreales }\end{array}$} & \multirow{3}{*}{$\begin{array}{l}\text { Fusarium } \\
\text { oxysporum f. sp. } \\
\text { lycopersici }\end{array}$} & \multirow[t]{3}{*}{ Fol-4287 } & $\begin{array}{l}\text { ACs: } \mathrm{Chr} 3,6,14,15 \\
(0.2 \text { to } 1.3 \mathrm{Mb})\end{array}$ & $\begin{array}{l}\text { Secreted-in-xylem } \\
\text { pathogenicity genes }\end{array}$ & Virulence (tomato) & Electrophoretic karyotype; & \multirow{3}{*}{$\begin{array}{l}\text { Elmore et al. 2015; Ma } \\
\text { et al. 2010; Schmidt et al. } \\
\text { 2013; van der Does et al. } \\
\text { 2016; Vlaardingerbroek } \\
\text { et al. 2016a; Williams } \\
\text { et al. } 2016\end{array}$} \\
\hline & & & ARs: $\mathrm{Chr} 1$ and 2 & $\begin{array}{l}\text { Transcription factors } \\
\text { regulating effector gene } \\
\text { expression }\end{array}$ & $\begin{array}{l}\text { CCA gene cluster: } \\
\text { possible HGT } \\
\text { from } \\
\text { Cochliobolus } \\
\text { lunatus or } \\
\text { Oidiodendron } \\
\text { maius }\end{array}$ & $\begin{array}{l}\text { AC-specific PCR; Southern } \\
\text { hybridization; flow } \\
\text { cytometry }\end{array}$ & \\
\hline & & & & $\begin{array}{l}\text { CCA gene cluster (three } \\
\text { copies) }\end{array}$ & $\begin{array}{l}\text { Enriched for } \\
\text { predicted } \\
\text { pathogenicity loci }\end{array}$ & & \\
\hline $\begin{array}{l}\text { Sordariomycetes } \\
\text { Hypocreales }\end{array}$ & $\begin{array}{l}\text { Fusarium } \\
\text { oxysporum f. sp. } \\
\text { medicaginis \# }\end{array}$ & Fom-5190a & Multiple scaffolds & Unknown & $\begin{array}{l}\text { Enriched for } \\
\text { predicted } \\
\text { pathogenicity loci }\end{array}$ & $\begin{array}{l}\text { Prediction-bioinformatic } \\
\text { subtraction of core- } \\
\text { chromosome matches }\end{array}$ & Williams et al. 2016 \\
\hline $\begin{array}{l}\text { Sordariomycetes } \\
\text { Hypocreales }\end{array}$ & $\begin{array}{l}\text { Fusarium } \\
\text { oxysporum f. sp. } \\
\text { melonis }\end{array}$ & NRRL 26406 & Multiple scaffolds & CCA gene cluster & $\begin{array}{l}\text { CCA gene cluster: } \\
\text { possible HGT } \\
\text { from } \\
\text { Cochliobolus } \\
\text { lunatus or } \\
\text { Oidiodendron } \\
\text { maius }\end{array}$ & $\begin{array}{l}\text { Prediction-bioinformatic } \\
\text { subtraction of core- } \\
\text { chromosome matches }\end{array}$ & $\begin{array}{l}\text { Elmore et al. 2015; } \\
\text { Williams et al. } 2016\end{array}$ \\
\hline $\begin{array}{l}\text { Sordariomycetes } \\
\text { Hypocreales }\end{array}$ & $\begin{array}{l}\text { Fusarium } \\
\text { oxysporum f. sp. } \\
\text { pisi }\end{array}$ & Fop-37622 & Multiple scaffolds & $\begin{array}{l}\text { PEP cluster defines host } \\
\text { range allowing pisatin } \\
\text { detoxification } \\
\text { CCA gene cluster }\end{array}$ & $\begin{array}{l}\text { CCA gene cluster: } \\
\text { possible HGT } \\
\text { from } \\
\text { Cochliobolus } \\
\text { lunatus or } \\
\text { Oidiodendron } \\
\text { maius }\end{array}$ & $\begin{array}{l}\text { Prediction-bioinformatic } \\
\text { subtraction of CC } \\
\text { matches }\end{array}$ & $\begin{array}{l}\text { Elmore et al. 2015; } \\
\quad \text { Williams et al. } 2016\end{array}$ \\
\hline $\begin{array}{l}\text { Sordariomycetes } \\
\text { Hypocreales }\end{array}$ & Fusarium poae & F. poae 2516 & $\begin{array}{l}172 \text { contigs } \\
\quad(\text { total } \sim 8.18 \mathrm{Mb})\end{array}$ & Unknown & $\begin{array}{l}\text { ZIT1 transposon } \\
\text { (marker for ACs) }\end{array}$ & $\begin{array}{l}\text { Prediction-bioinformatic } \\
\text { subtraction of CC } \\
\text { matches }\end{array}$ & $\begin{array}{l}\text { Coleman et al. 2009; } \\
\text { Mahmoud and Taga } \\
\text { 2012; Mehrabi et al. } \\
\text { 2011; Miao et al. 1991; } \\
\text { Temporini and VanEtten } \\
\text { 2002; Vanheule et al. } \\
\text { 2016; Wasmann and } \\
\text { VanEtten } 1996\end{array}$ \\
\hline $\begin{array}{l}\text { Sordariomycetes } \\
\text { Hypocreales }\end{array}$ & $\begin{array}{l}\text { Fusarium solani } \\
\text { (syn. } \\
\text { Haemonectria } \\
\text { hematococca) }\end{array}$ & ATCC18098 & $\begin{array}{l}\text { ACs: Chr 14, 15, } 17 \\
\text { Minichromosome } \\
\quad(410 \mathrm{~kb}) \text { (mendelian) }\end{array}$ & $\begin{array}{l}\text { PEP cluster, } P d a 6 \\
\text { cytochrome } \mathrm{p} 450\end{array}$ & $\begin{array}{l}\text { Virulence (pea, via } \\
\text { pisatin } \\
\text { demethylation) }\end{array}$ & $\begin{array}{l}\text { Electrophoretic karyotype; } \\
\text { FISH; AC-specific PCR }\end{array}$ & $\begin{array}{l}\text { Coleman et al. 2009; } \\
\text { Mahmoud and Taga } \\
\text { 2012; Mehrabi et al. } \\
\text { 2011; Miao et al. 1991; } \\
\text { Temporini and VanEtten } \\
\text { 2002; Wasmann and } \\
\text { VanEtten } 1996\end{array}$ \\
\hline $\begin{array}{l}\text { Sordariomycetes } \\
\text { Hypocreales }\end{array}$ & $\begin{array}{l}\text { Fusarium } \\
\text { verticillioides }\end{array}$ & $\begin{array}{l}\text { FGSC 7983, FGSC } \\
8067, \text { FGSC } 8070\end{array}$ & Chromosome 12 & Unknown & Unknown & Genetic map & Jurgenson et al. 2002 \\
\hline $\begin{array}{l}\text { Sordariomycetes } \\
\text { Hypocreales }\end{array}$ & $\begin{array}{l}\text { Metarhizium } \\
\text { anisopliae }\end{array}$ & Strain V275 & $\mathrm{AC}(1.05 \mathrm{Mb})$ & Destruxin biosynthesis & Virulence (insects) & Electrophoretic karyotype & Wang et al. 2003 \\
\hline \multirow[t]{2}{*}{$\begin{array}{l}\text { Sordariomycetes } \\
\text { Hypocreales }\end{array}$} & \multirow[t]{2}{*}{$\begin{array}{l}\text { Verticillium } \\
\text { dahliae }\end{array}$} & \multirow[t]{2}{*}{ JR2 } & $\begin{array}{l}4 \mathrm{ARs}(\sim 2 \mathrm{Mb}) \\
\text { (prediction) }\end{array}$ & Avel biosynthesis & & \multirow[t]{2}{*}{ In silico read mapping } & \multirow{2}{*}{$\begin{array}{l}\text { de Jonge et al. 2013; Faino } \\
\text { et al. 2016; Klosterman } \\
\text { et al. 2011 }\end{array}$} \\
\hline & & & $\begin{array}{l}\text { AR: Chr } 5 \text { (race } 2 \\
\text { strains) }\end{array}$ & Avel biosynthesis & $\begin{array}{l}\text { Enriched for in } \\
\text { planta-expressed } \\
\text { effectors }\end{array}$ & & \\
\hline $\begin{array}{l}\text { Sordariomycetes } \\
\text { Magnaporthales }\end{array}$ & $\begin{array}{l}\text { Magnaporthe } \\
\text { oryzae }\end{array}$ & $\begin{array}{l}\text { Reference strain 70-15 } \\
\text { (no ACs) } \\
\text { with ACs: 4224-7-8, } \\
\text { P131, Y34, FJ81278, } \\
\text { 84R-62B, GFSI1-7-2, } \\
\text { and HN19311 }\end{array}$ & $\begin{array}{l}1 \text { to } 4 \text { minichromosomes } \\
(0.4 \text { to } 2.2 \mathrm{Mb}) \\
2 \text { ACs: strains } 84 \mathrm{R}-62 \mathrm{~B} \\
\text { (1.6 Mb, mendelian) } \\
\text { and GFSI1-7-2 (1.2 } \\
\text { Mb, nonmendelian) }\end{array}$ & AvrPik avirulence effector & $\begin{array}{l}\text { 1.6 Mb AC: } \\
\text { Virulence (rice) } \\
\text { and duplications } \\
\text { from Chr } 1 \text { and } 17\end{array}$ & $\begin{array}{l}\text { Electrophoretic karyotype; } \\
\text { Southern hybridization; } \\
\text { comparative genomics }\end{array}$ & $\begin{array}{l}\text { Chen et al. 2013; Chuma } \\
\text { et al. 2011; Luo et al. } \\
\text { 2007; Talbot et al. 1993; } \\
\text { Xue et al. } 2012\end{array}$ \\
\hline
\end{tabular}


by their host specificity, itself largely determined by their AC content (Ma et al. 2010; van Dam et al. 2016; Williams et al. 2016). Across $F$. oxysporum formae speciales, the size of the core genome is relatively conserved, while the $\mathrm{AC}$ and $\mathrm{AR}$ content is variable (van Dam et al. 2016; Williams et al. 2016). All known pathogenic isolates possess an $\mathrm{AC}$, homologous to the tomato-infecting isolate 4287 chromosome 14, encoding several 'secreted-in-xylem' proteins that confer pathogenicity, and their presence can be used to predict host specificity (van Dam et al. 2016). Recombination between upstream Helitron TEs has been proposed to have driven the evolution of separate races in this species (Schmidt et al. 2013; Vlaardingerbroek et al. 2016a). Genetic maps have also identified a $0.7-\mathrm{Mb}$ AC of Fusarium verticillioides (Jurgenson et al. 2002). Fusarium spp. have also been shown to have distinct epigenetic profiles within ACs compared with CCs, which has facilitated further predictions of ACs based solely on epigenetic profiling in $F$. asiaticum and F. fujikuroi (Table 1) (Galazka and Freitag 2014).

The causal agent of septoria tritici blotch of wheat, Zymoseptoria tritici (syn. Mycosphaerella graminicola), is another well-studied species with confirmed ACs. Karyotyping detected isolates with up to 21 chromosomes (Goodwin et al. 2011; Zolan 1995). The 'finished' genome of the reference isolate IPO323 contains eight ACs ranging from 409 to $773 \mathrm{~kb}$ - the highest number observed so far. An additional finished genome of isolate 3D7 contains four of the ACs present in IPO323 (Plissonneau et al. 2016). The origin of the Z. tritici ACs was proposed to have occurred via lateral transfer followed by sequence mutation and recombination events (Goodwin et al. 2011). Recently, they were proposed to have stemmed from ancient CC duplications (nondisjunction) followed by degradation via breakage fusion bridge (BFB) cycles and RIP on duplicated sequences (Croll et al. 2013). Approximately half of Z. tritici ACs are paralogs of CC genes (Croll and McDonald 2012; Goodwin et al. 2011). In contrast to ACs in Fusarium spp., although Zymoseptoria ACs exhibit many typical features, they are not enriched in predicted secreted genes and encode no characterized pathogenicity loci (Ware 2006). Nevertheless, recent genetic mapping studies report a small but significant association with virulence for four ACs (IPO323 chromosomes 14, 15, 18, and 21) (Stewart et al. 2018) (Table 1). Z. pseudotritici and Z. ardabiliae also possess at least six and four ACs, respectively, which are homologous to ACs of Z. tritici (Kellner et al. 2014; Stukenbrock et al. 2012) (Table 1).

Several other species have confirmed ACs with direct roles in plant pathogenicity (Table 1). Alternaria spp. are predominantly saprophytic, yet four species have acquired plant pathogenicity via ACs of 1 to $2 \mathrm{Mb}$ (Akamatsu et al. 1999) that encode TOX genes involved in the synthesis of necrotrophic effectors (host-specific toxins) (Akamatsu et al. 1999; Tsuge et al. 2013, 2016). These effector biosynthesis genes have been extensively duplicated and their copy number is quantitatively correlated with virulence (Akagi et al. 2009; Harimoto et al. 2007; Hatta et al. 2002; Johnson et al. 2000; Masunaka et al. 2005; Miyamoto et al. 2008; Ruswandi et al. 2005; Tanaka and Tsuge 2000). In Colletotrichum gloeosporioides, vegetatively incompatible biotypes A and B infect tropical legumes of Stylosanthes spp. causing either type A or type B anthracnose, respectively. Biotype A isolates commonly carry a $2-\mathrm{Mb} \mathrm{AC}$, while only biotype $\mathrm{B}$ isolates belonging to race 3 are observed to carry a 1.2-Mb homologous AC (He et al. 1998). Transfer of the 2-Mb AC from biotype A to B can confer type A anthracnose symptoms to the type B recipient (He et al. 1998). However, ACs in other Colletotrichum spp. are less well-defined. C. graminicola has three minichromosomes less than $1 \mathrm{Mb}$ in size and $C$. higginsianum has two minichromosomes (O'Connell et al. 2012); all five ACs are repeat-rich and lack homology to chromosomes of other Colletotrichum spp. Chromosomes of
C. lindemuthianum show CLP and PAV, which may indicate ACs in this species as well (O'Sullivan et al. 1998). In Leptosphaeria maculans (causal agent of black leg or phoma canker of canola) there is an approximately $1-\mathrm{Mb} \mathrm{AC}$ encoding the avirulence effector gene AvrRlmll conferring virulence on Brassica rapa or avirulence in the presence of the Rlml1 resistance gene (Balesdent et al. 2013; Cozijnsen et al. 2000; Leclair et al. 1996; Plummer and Howlett 1995). Approximately one third of the L. maculans genome is also compartmentalized into interspersed transposon- and AT-rich regions, which also frequently harbor avirulence effectors (Rouxel et al. 2011; Testa et al. 2016; Van de Wouw et al. 2010) and have AC- and AR-like properties (Balesdent et al. 2013). Magnaporthe oryzae, causal agent of rice blast, has several minichromosomes ranging from $470 \mathrm{~kb}$ to $2.2 \mathrm{Mb}$ (Talbot et al. 1993) and two confirmed ACs, a 1.2-Mb AC (Chuma et al. 2011) and a 1.6-Mb AC containing the avirulence gene AvrPik (Luo et al. 2007). Independent comparative genomics studies between different pairs of field isolates have also reported ARs (totaling approximately $1.75 \mathrm{Mb}$ ) with AC- and AR-like properties (Chen et al. 2013; Xue et al. 2012). Cochliobolus heterostrophus (southern corn leaf blight) has one $\mathrm{AC}$ (chromosome 16), present in race T isolates and absent from race $\mathrm{O}$, as well as an estimated 1.2-Mb AR (Condon et al. 2013; Tzeng et al. 1992). This AR contains Toxl, which encodes proteins that synthesize the polyketide T-toxin conferring virulence on Texas male sterile cytoplasm corn (Kodama et al. 1999) (Table 1).

In other fungal species, preliminary data are available supporting the presence of ACs (Table 1). In the broad-host range pathogen Macrophomina phaseolina, from zero to six ACs were observed in isolates ranging from $785 \mathrm{~Kb}$ to approximately $2 \mathrm{Mb}$ (Jones et al. 1998). PAV patterns between isolates are highly variable and there is not a clear association between AC content and host range. Verticillium spp. include several pathogens causing vascular wilt diseases with wide host ranges and are asexual despite rare recombination events occurring as a result of parasexual processes (Milgroom et al. 2014; O'Garro and Clarkson 1992). For $V$. dahliae and V. albo-atrum, karyotyping has indicated CLPs but not ACs (Pantou and Typas 2005). Subsequent comparative genomics revealed four ARs (approximately $300 \mathrm{~Kb}$ ) with AC- and AR-like properties present in $V$. dahliae and absent in $V$. albo-atrum (Klosterman et al. 2011). Further comparison of eleven $V$. dahliae isolates revealed interspersed ARs totalling approximately $4 \mathrm{Mb}$, with one isolate containing race 1-specific effector gene Avel (de Jonge et al. 2013; Faino et al. 2016). TEs have been proposed to drive diversification within $V$. dahliae ARs by triggering largescale rearrangements, duplication, and loss (Faino et al. 2016). The recently finished genomic sequence of Botrytis cinerea isolate B05.10 identified two small ACs $(<250 \mathrm{~kb})$, with chromosome 18 wholly absent and chromosome 17 partially absent from isolate 09Bc11 (Van Kan et al. 2017). Karyotyping of the necrotroph Parastagonospora nodorum (septoria nodorum blotch of wheat) identified an AC of 300 to $700 \mathrm{~kb}$ that was only reported for strains isolated from wheat or barley (Caten and Newton 2000; Cooley and Caten 1991; Zolan 1995). Bioinformatic prediction of altered gene and repeat density also predicted a $P$. nodorum scaffold as a putative AR $(\mathrm{Ohm}$ et al. 2012), however, it does not contain any of its known necrotrophic effector loci (Crook et al. 2012; Tan et al. 2014), which all reside on large sequences (Syme et al. 2013).

\section{MECHANISMS OF GAIN, LOSS, AND MUTAGENESIS IN ACS}

ACs can potentially be lost or transferred between isolates, although both are likely to be rare events. The rate of loss of 
chromosome 14 of $F$. oxysporum f. sp. lycopersici was measured at 1 in 35,000 spores (Vlaardingerbroek et al. 2016b). The mechanism of BFB cycles (McClintock 1941) combined with large sequence insertions have been proposed as a putative cause of AC formation and loss (Croll et al. 2013). BFB cycles begin with loss of telomeres causing instability at the distal regions of chromosomes and potential fusion of sister chromatids. Products of BFB cycles depend on the site of breakage during the separation of erroneously fused sister chromatids, which may lead to sequence duplication, deletion, rearrangement, or the creation of new minichromosomes. In support of this model, telomeric regions and ACs share many similar sequence properties (Galazka and Freitag 2014). Notably, the ARs on partially dispensable chromosomes of $F$. oxysporum f. sp. lycopersici are located near the telomeres (Ma et al. 2010), suggesting that these may be BFB-affected regions that have not become separate chromosomes. In the genome of a closely related species, F. graminearum, there are hypervariable 'hotspot' regions that also present AC-like characteristics and appear to be fused subtelomeric regions of homologous CCs that are conserved across Fusarium spp. (King et al. 2015; Ma et al. 2010). A 1.6-Mb AC of Magnaporthe oryzae contains a duplicated distal region of CC 1 (Luo et al. 2007). MGCs, which are frequently laterally transferred between distant fungal species, are also biased toward subtelomeric regions (Galazka and Freitag 2014; Wisecaver and Rokas 2015). Surprisingly, the formation of Fusarium ACs appears to be reversible, as comparison of multiple isolates showed some AC regions had translocated back into the core genome, with a location bias toward subtelomeric regions (Vanheule et al. 2016). This may indicate that following BFB-mediated formation, it is possible for an $\mathrm{AC}$ to be reintegrated into a $\mathrm{CC}$ (Fig. 1).

ACs may be gained by deficient isolates via the fusion of conidial anastomosis tubes (CATs) between hyphal cells (Roca et al. 2003). The formation of CATs, specialized hyphae that mediate cell fusion uniquely during colony initiation, results in a state of heterokaryosis (Galazka and Freitag 2014; Strom and Bushley 2016; Wisecaver and Rokas 2015), in which two nuclei are present within a single cell. Heterokaryosis may facilitate nonmeiotic recombination between homologous chromosomes, and slow-growing heterokaryons have been hypothesized to be the intermediate step for AC transfer (Manners and He 2011). The fusion of CATs is usually limited (or entirely prevented) by vegetative incompatibility (vic) genes (Paoletti 2016) and the continued viability of successful fusions is then determined by heterokaryotic incompatibility (het) genes (Strom and Bushley 2016). Incompatible vic interactions are unable to undergo CAT fusion, and incompatible het interactions trigger local and surrounding cell death (Strom and Bushley 2016). The presence of some ACs may influence compatibility, as predicted ACs of F. oxysporum have been observed to be enriched in het genes (Schmidt et al. 2013; Williams et al. 2016). CATs themselves

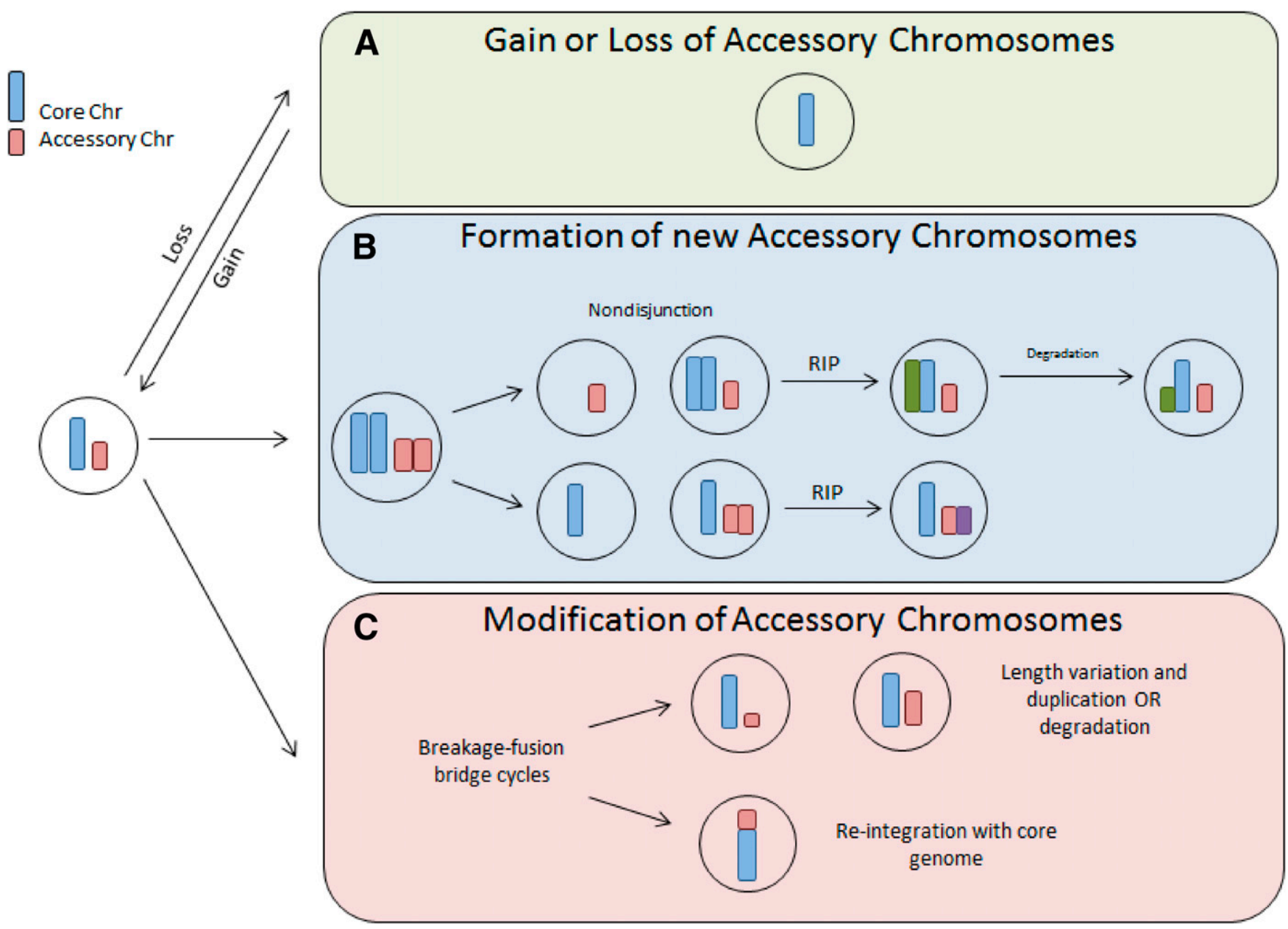

Fig. 1. Summary of potential genome evolutionary processes involving fungal accessory chromosome gain and loss, formation, and modification. A, Accessory chromosomes may be lost due to linkage disequilibrium or gained through lateral transfer. B, New accessory chromosomes may be formed through duplication via nondisjunction. The sequence of duplicated chromosomes may be mutated by repeat induced point mutation (RIP), and larger duplicated core chromosomes may become degraded into shorter chromosomes over time. C, The structure of accessory chromosomes may be modified by breakage-fusion bridge cycles resulting in shortening or addition of duplicated sequence or fusion with another chromosome. 
may have a suppressive effect on incompatibility relative to other types of hyphal fusions, as observed in $C$. lindemuthianum (Ishikawa et al. 2012; Ma et al. 2010). In addition to the exchange of genetic material between individual isolates of the same species, CATs may also facilitate lateral gene transfer (LGT) (Coleman et al. 2009; Ma et al. 2010; Mehrabi et al. 2011; $\mathrm{Hu}$ et al. 2012) between different species. A relatively distant LGT from Aspergillus spp. has been proposed as the origin of F. solani ACs (Coleman et al. 2009); however, they may also have emerged prior to the divergence of these two genera (Croll and McDonald 2012). Transfers of ACs conferring increased virulence have been observed under laboratory conditions for F. oxysporum (Ma et al. 2010), A. alternata (Vlaardingerbroek et al. 2016a), and C. gloeosporioides (Manners and He 2011). Isolates of $F$. oxysporum have also been observed to exhibit different rates of lateral transfer between similarly sized ACs, and CCs were also rarely observed to be partially transferred when there was also cotransfer of an AC (Vlaardingerbroek et al. 2016a).

Many ACs and ARs exhibit high levels of sequence polymorphism or disruption of chromosomal colinearity. The majority of the lengths of ACs and ARs do not appear to be under strong selection pressures and ACs are more likely to retain mutations than CCs, likely due to their gene scarcity. Therefore, over time, sequence and structural variations may accumulate within ACs. Their high repetitive DNA contents also make them prone to the activity of RIP (Hane et al. 2015). RIP is a fungal-specific mechanism of mutagenesis that targets repetitive DNA or duplicated elements in the genome, causing $\mathrm{C}$ to $\mathrm{T}$ single nucleotide polymorphism (SNP) transitions. The accumulation of RIP can also influence the epigenetic state of sequences (Lewis et al. 2009), altering its physical accessibility and, thus, its availability for mRNA transcription (Taga et al. 1999). Chromosome instability also affects the internal structure of ACs and ARs (Hane et al. 2011) and there is evidence for locational biases of structural rearrangements. F. oxysporum f. sp. lycopersici ACs possess hotspots in which sequences are commonly deleted between isolates that are nonrandomly distributed and do not share conserved sequence motifs (Vlaardingerbroek et al. 2016a and b). Similar locational biases were observed across multiple isolates of the closely related F. poae (Vanheule et al. 2016). Moreover, synteny comparisons between $F$. oxysporum f. sp. lycopersici and $F$. solani show a distinct variation in the accumulation of intrachromosomal rearrangements between CCs and ACs, in which ACs either lacked homologs or presented mesosyntenic patterns (Hane et al. 2011). The process of intrachromosomal rearrangement resulting in patterns of mesosynteny (Hane et al. 2011; Ohm et al. 2012) is likely a result of accumulating numerous inversions, which are associated with low-complexity DNA (i.e., simple repeat) regions (Ellison et al. 2011; Ohm et al. 2012) or repetitive DNA (including transposons) (Faino et al. 2016). The dual association with RIP and structural rearrangements make repetitive DNA a major driver of genome evolution in ACs and ARs.

\section{EVOLUTION OF ACCESSORY SEQUENCES AND PATHOGENICITY}

Accessory chromosomes and genomic regions are, by definition, not required for survival yet, in some cases, harbor genes that confer a major competitive advantage under specific conditions. Many fungal ACs and ARs harbor pathogenicity genes (Table 1), which include effectors, secondary metabolite biosynthesis clusters or other MGCs. There is a common theme among plant-pathogenic fungi of 'two-speed genome evolution', or the separation of their genomes into compartments comprised of core conserved regions and highly plastic regions.
Plastic compartments, including ACs, ARs and other AT-rich regions (Testa et al. 2016), which have been described as "the cradle for adaptive evolution" (Croll and McDonald 2012), are highly variable in sequence and structure and, typically, accumulate RIP and other SNP mutations (Oliver 2012; Raffaele and Kamoun 2012; Rouxel et al. 2011; Vanheule et al. 2016; Williams et al. 2016) and mesosyntenic rearrangements (Hane et al. 2011; Ohm et al. 2012) more rapidly than the core genome. The location of pathogenicity loci within these plastic compartments often results in their rapid diversification, which can be advantageous if their gene products are recognized by host defenses (Jones and Dangl 2006). The extent of compartmentalization across fungal species appears to vary considerably according to mode of infection and evolutionary history, with evidence that at least AT-rich regions are more strongly associated with pathogens that reside asymptomatically on the host for longer periods (Testa et al. 2016) (Table 1). Compartmentalization may allow the diversification of nonessential genes to be accelerated within ACs and ARs, while genes encoding essential functions on CCs can remain relatively static over time, either through targeted mutations or compartment-based selection. Thus, differentiation of genes into core and accessory regions likely permits normal growth and metabolism while also allowing rapid adaptation to periodically challenging stimuli (e.g., environmental stress, nutrient deficiency, and disease resistance).

RIP is a major driver of the evolution of pathogenicity loci in repeat-rich ACs and ARs (Hane et al. 2015), which, although targeted to repeats, can also 'leak' outwards into single-copy regions (Irelan et al. 1994), rapidly mutating nearby genes (Fudal et al. 2009; Testa et al. 2016; Van de Wouw et al. 2010). RIP leakage has been observed to accelerate one or both the mutation and loss of avirulence effectors that are recognized by corresponding resistance genes of their hosts, e.g., L. maculans (Balesdent et al. 2013; Van de Wouw et al. 2010). Homology between ACs and CCs, either via duplication or TE activity would drive RIP-mediated 'hypermutation' (and potentially further RIP leakage) targeted to the homologous regions within the otherwise relatively stable CCs (Dhillon et al. 2010). RIP can also be a major factor influencing the conditional expression of pathogenicity genes during infection. When RIP acts upon repeated sequences and depletes GC content, it enhances the accumulation of simple AT-rich sequences (Testa et al. 2016) and promotes the binding of DNA methylation modifier proteins (Singer and Selker 1995; Tamaru and Selker 2003). This, in turn, leads to histone modifications resulting in tightly packed and transcriptionally inactive heterochromatin (Connolly et al. 2013; Galazka and Freitag 2014; Lewis et al. 2009; Taga et al. 1999) and may influence the conditional expression of pathogenicity genes during infection. ACs and ARs of Z. tritici (Schotanus et al. 2015; Soyer et al. 2015) and L. maculans (Soyer et al. 2014) are enriched for one or both chromatin modifications H3K9me3 and H3K27me3, which suppress gene expression across large regions of DNA but may be lifted in response to stimuli such as host infection (de Jonge et al. 2013; van der Does et al. 2016). Indeed, L. maculans effectors residing in AT-rich regions have been observed to be expressed early during infection, in contrast to effectors in GC-equilibrated regions that are expressed later (Gervais et al. 2016). Chromatin modifications in ACs and ARs may also facilitate the coregulation and preserve the structural integrity of MGCs by preventing structural rearrangements (Galazka and Freitag 2014).

\section{CONCLUSIONS AND FUTURE PERSPECTIVES}

ACs and ARs are reported across a wide range of fungal taxa but, predominantly, from pathogenic species. Although this may 
reflect a bias in the species studied, many reported fungal ACs also have demonstrated roles in plant pathogenicity. Compartmentalization of gene content is an important strategy for genome adaptation and innovation, particularly in the context of pathogenicity. We speculate a possible model for the 'birth and death' of fungal genes, in which loci could conceivably be i) mobilized by BFB-cycles and other structural rearrangements, ii) potentially group into functionally related clusters, iii) become rapidly mutated within $\mathrm{AC}$ and $\mathrm{AR}$ compartments in which they may undergo selection for a useful phenotype, and iv) potentially reintegrate into stable CCs (Fig. 1).

Continued study of ACs and ARs in pathogen genomes will assist in the identification of novel pathogenicity genes. Much of our understanding of ACs and ARs has been learned through study of species with high-quality genomic resources, i.e., finished genome assemblies, resequencing data for multiple isolates, or both. With advances in genome sequencing now permitting chromosome-scale assembly and affordable resequencing of populations, the discovery and routine screening of ACs and ARs will become an increasingly useful tool in modern molecular plant pathology. Past AC discoveries have revealed key pathogenicity genes, including host-specific virulence factors and phytoalexin degradation enzymes (Table 1). Thus, further detection of ACs are likely to yield more novel disease markers. Trends in genomics toward full or near chromosome-length genome assembly are improving fungal genome resources from fragmented assemblies toward being capable of providing reliable information on the genome landscape and its compartmentalization. Yet accuracy remains an issue for current long-read sequencing platforms, often relying on short reads to improve base call accuracy. While this performs well for the assembly of gene-rich regions and overall chromosome structure, this may be problematic for the resolution of repeat-rich regions. Without overcoming this barrier, the roles of transposon repeats and fungal-specific RIP in AC evolution and the interplay of these factors between ACs and CCs cannot be intensively studied. Accessory chromosomes have been well-studied in both plants and animals, albeit often under the term B chromosomes; however, their further study in Fungi may yet provide unique insight into the relationship between ACs and fungal-specific genome mutation phenomena such as RIP (Hane et al. 2015), elevated rates of intrachromosomal rearrangement (Hane et al. 2011), and LGT (Akagi et al. 2009; He et al. 1998; Hu et al. 2012; Ma et al. 2010; Mehrabi et al. 2011; Vlaardingerbroek et al. 2016a) observed in the Fungi.

\section{ACKNOWLEDGMENTS}

The authors gratefully acknowledge R. Oliver for constructive feedback.

\section{LITERATURE CITED}

Akagi, Y., Akamatsu, H., Otani, H., and Kodama, M. 2009. Horizontal chromosome transfer, a mechanism for the evolution and differentiation of a plant-pathogenic fungus. Eukaryot. Cell 8:1732-1738.

Akamatsu, H., Taga, M., Kodama, M., Johnson, R., Otani, H., and Kohmoto, K. 1999. Molecular karyotypes for Alternaria plant pathogens known to produce host-specific toxins. Curr. Genet. 35:647-656.

Arango Isaza, R. E., Diaz-Trujillo, C., Dhillon, B., Aerts, A., Carlier, J., Crane, C. F., de Jong, T. V., de Vries, I., Dietrich, R., Farmer, A. D., Fortes Fereira, C., Garcia, S., Guzman, M., Hamelin, R. C., Lindquist, E. A., Mehrabi, R., Quiros, O., Schmutz, J., Shapiro, H., Reynolds, E., Scalliet, G., Souza, M., Jr., Stergiopoulos, I., Van der Lee, T. A. J., De Wit, P. J. G. M., Zapater, M.-F., Zwiers, L.-H., Grigoriev, I. V., Goodwin, S. B., and Kema, G. H. J. 2016. Combating a global threat to a clonal crop: Banana black Sigatoka pathogen Pseudocercospora fijiensis (synonym Mycosphaerella fijiensis) genomes reveal clues for disease control. PLoS Genet. 12:e1005876.
Balesdent, M. H., Fudal, I., Ollivier, B., Bally, P., Grandaubert, J., Eber, F., Chèvre, A. M., Leflon, M., and Rouxel, T. 2013. The dispensable chromosome of Leptosphaeria maculans shelters an effector gene conferring avirulence towards Brassica rapa. New Phytol. 198:887-898.

Caten, C., and Newton, A. 2000. Variation in cultural characteristics, pathogenicity, vegetative compatibility and electrophoretic karyotype within field populations of Stagonospora nodorum. Plant Pathol. 49:219-226.

Chen, C., Lian, B., Hu, J., Zhai, H., Wang, X., Venu, R. C., Liu, E., Wang, Z., Chen, M., Wang, B., Wang, G. L., Wang, Z., and Mitchell, T. K. 2013. Genome comparison of two Magnaporthe oryzae field isolates reveals genome variations and potential virulence effectors. BMC Genomics 14: 887.

Chuma, I., Hotta, Y., and Tosa, Y. 2011. Instability of subtelomeric regions during meiosis in Magnaporthe oryzae. J. Gen. Plant Pathol. 77:317-325.

Coleman, J. J., Rounsley, S. D., Rodriguez-Carres, M., Kuo, A., Wasmann, C. C., Grimwood, J., Schmutz, J., Taga, M., White, G. J., Zhou, S., Schwartz, D. C., Freitag, M., Ma, L. J., Danchin, E. G., Henrissat, B., Coutinho, P. M., Nelson, D. R., Straney, D., Napoli, C. A., Barker, B. M., Gribskov, M., Rep, M., Kroken, S., Molnár, I., Rensing, C., Kennell, J. C., Zamora, J., Farman, M. L., Selker, E. U., Salamov, A., Shapiro, H., Pangilinan, J., Lindquist, E., Lamers, C., Grigoriev, I. V., Geiser, D. M., Covert, S. F., Temporini, E., and Vanetten, H. D. 2009. The genome of Nectria haematococca: Contribution of supernumerary chromosomes to gene expansion. PLoS Genet. 5:e1000618.

Condon, B. J., Leng, Y., Wu, D., Bushley, K. E., Ohm, R. A., Otillar, R., Martin, J., Schackwitz, W., Grimwood, J., MohdZainudin, N., Xue, C., Wang, R., Manning, V. A., Dhillon, B., Tu, Z. J., Steffenson, B. J., Salamov, A., Sun, H., Lowry, S., LaButti, K., Han, J., Copeland, A. Lindquist, E., Barry, K., Schmutz, J., Baker, S. E., Ciuffetti, L. M., Grigoriev, I. V., Zhong, S., and Turgeon, B. G. 2013. Comparative genome structure, secondary metabolite, and effector coding capacity across Cochliobolus pathogens. PLoS Genet. 9:e1003233.

Connolly, L. R., Smith, K. M., and Freitag, M. 2013. The Fusarium graminearum histone H3 K27 methyltransferase KMT6 regulates development and expression of secondary metabolite gene clusters. PLoS Genet. 9:e1003916.

Cooley, R. N., and Caten, C. E. 1991. Variation in electrophoretic karyotype between strains of Septoria nodorum. Mol. Gen. Genet. 228:17-23.

Covert, S. F. 1998. Supernumerary chromosomes in filamentous fungi. Curr. Genet. 33:311-319.

Cozijnsen, A. J., Popa, K. M., Purwantara, A., Rolls, B. D., and Howlett, B. J. 2000. Genome analysis of the plant pathogenic ascomycete Leptosphaeria maculans; mapping mating type and host specificity loci. Mol. Plant Pathol. 1:293-302.

Croll, D., and McDonald, B. A. 2012. The accessory genome as a cradle for adaptive evolution in pathogens. PLoS Pathog. 8:e1002608.

Croll, D., Zala, M., and McDonald, B. A. 2013. Breakage-fusion-bridge cycles and large insertions contribute to the rapid evolution of accessory chromosomes in a fungal pathogen. PLoS Genet. 9:e1003567.

Crook, A. D., Friesen, T. L., Liu, Z. H., Ojiambo, P. S., and Cowger, C. 2012. Novel necrotrophic effectors from Stagonospora nodorum and corresponding host sensitivities in winter wheat germplasm in the southeastern United States. Phytopathology 102:498-505.

de Jonge, R., Bolton, M. D., Kombrink, A., van den Berg, G. C., Yadeta, K. A., and Thomma, B. P. 2013. Extensive chromosomal reshuffling drives evolution of virulence in an asexual pathogen. Genome Res. 23: 1271-1282.

Dhillon, B., Cavaletto, J. R., Wood, K. V., and Goodwin, S. B. 2010 Accidental amplification and inactivation of a methyltransferase gene eliminates cytosine methylation in Mycosphaerella graminicola. Genetics 186:67-77.

Ellison, C. E., Stajich, J. E., Jacobson, D. J., Natvig, D. O., Lapidus, A., Foster, B., Aerts, A., Riley, R., Lindquist, E. A., Grigoriev, I. V., and Taylor, J. W. 2011. Massive changes in genome architecture accompany the transition to self-fertility in the filamentous fungus Neurospora tetrasperma. Genetics 189:55-69.

Elmore, M. H., McGary, K. L., Wisecaver, J. H., Slot, J. C., Geiser, D. M., Sink, S., O'Donnell, K., and Rokas, A. 2015. Clustering of two genes putatively involved in cyanate detoxification evolved recently and independently in multiple fungal lineages. Genome Biol. Evol. 7:789-800.

Faino, L., Seidl, M. F., Shi-Kunne, X., Pauper, M., van den Berg, G. C., Wittenberg, A. H., and Thomma, B. P. 2016. Transposons passively and actively contribute to evolution of the two-speed genome of a fungal pathogen. Genome Res. 26:1091-1100.

Fudal, I., Ross, S., Brun, H., Besnard, A.-L., Ermel, M., Kuhn, M.-L. Balesdent, M.-H., and Rouxel, T. 2009. Repeat-induced point mutation (RIP) as an alternative mechanism of evolution toward virulence in Leptosphaeria maculans. Mol. Plant-Microbe Interact 22:932-941. 
Galazka, J. M., and Freitag, M. 2014. Variability of chromosome structure in pathogenic fungi-of 'ends and odds'. Curr. Opin. Microbiol. 20:19-26. Gervais, J., Plissonneau, C., Linglin, J., Meyer, M., Labadie, K., Cruaud, C., Fudal, I., Rouxel, T., and Balesdent, M.-H. 2016. Different waves of effector genes with contrasted genomic location are expressed by Leptosphaeria maculans during cotyledon and stem colonization of oilseed rape. Mol. Plant Pathol. 18:1113-1126.

Goodwin, S. B., M'barek, S. B., Dhillon, B., Wittenberg, A. H., Crane, C. F., Hane, J. K., Foster, A. J., Van der Lee, T. A., Grimwood, J., Aerts, A., Antoniw, J., Bailey, A., Bluhm, B., Bowler, J., Bristow, J., van der Burgt, A., Canto-Canché, B., Churchill, A. C., Conde-Ferràez, L., Cools, H. J., Coutinho, P. M., Csukai, M., Dehal, P., De Wit, P., Donzelli, B., van de Geest, H. C., van Ham, R. C., Hammond-Kosack, K. E., Henrissat, B., Kilian, A., Kobayashi, A. K., Koopmann, E., Kourmpetis, Y., Kuzniar, A., Lindquist, E., Lombard, V., Maliepaard, C., Martins, N., Mehrabi, R., Nap, J. P., Ponomarenko, A., Rudd, J. J., Salamov, A., Schmutz, J., Schouten, H. J., Shapiro, H., Stergiopoulos, I., Torriani, S. F., Tu, H., de Vries, R. P., Waalwijk, C., Ware, S. B., Wiebenga, A., Zwiers, L. H., Oliver, R. P., Grigoriev, I. V., and Kema, G. H. 2011. Finished genome of the fungal wheat pathogen Mycosphaerella graminicola reveals dispensome structure, chromosome plasticity, and stealth pathogenesis. PLoS Genet. 7:e1002070.

Hane, J. K., Rouxel, T., Howlett, B. J., Kema, G. H., Goodwin, S. B., and Oliver, R. P. 2011. A novel mode of chromosomal evolution peculiar to filamentous Ascomycete fungi. Genome Biol. 12:R45.

Hane, J. K., Williams, A. H., Taranto, A. P., Solomon, P. S., and Oliver, R. P. 2015. Repeat-induced point mutation: a fungal-specific, endogenous mutagenesis process. Pages 55-68 in: Genetic Transformation Systems in Fungi, Vol. 2. N. S. Iacobellis, A. Collmer, S.W. Hutcheson, J. W. Mansfield, C. E. Morris, J. Murillo, N. W. Schaad, D. E. Stead, G. Surico, and M. Ullrich, eds. Kluwer Academic Springers, Dordrecht, The Netherlands.

Harimoto, Y., Hatta, R., Kodama, M., Yamamoto, M., Otani, H., and Tsuge, T. 2007. Expression profiles of genes encoded by the supernumerary chromosome controlling AM-toxin biosynthesis and pathogenicity in the apple pathotype of Alternaria alternata. Mol. Plant-Microbe Interact 20: 1463-1476.

Hatta, R., Ito, K., Hosaki, Y., Tanaka, T., Tanaka, A., Yamamoto, M., Akimitsu, K., and Tsuge, T. 2002. A conditionally dispensable chromosome controls host-specific pathogenicity in the fungal plant pathogen Alternaria alternata. Genetics 161:59-70.

He, C., Rusu, A. G., Poplawski, A. M., Irwin, J. A., and Manners, J. M 1998. Transfer of a supernumerary chromosome between vegetatively incompatible biotypes of the fungus Colletotrichum gloeosporioides. Genetics 150:1459-1466.

Hu, J., Chen, C., Peever, T., Dang, H., Lawrence, C., and Mitchell, T. 2012. Genomic characterization of the conditionally dispensable chromosome in Alternaria arborescens provides evidence for horizontal gene transfer. BMC Genomics 13:171.

Irelan, J. T., Hagemann, A. T., and Selker, E. U. 1994. High frequency repeat-induced point mutation (RIP) is not associated with efficient recombination in Neurospora. Genetics 138:1093-1103.

Ishikawa, F. H., Souza, E. A., Shoji, J. Y., Connolly, L., Freitag, M., Read, N. D., and Roca, M. G. 2012. Heterokaryon incompatibility is suppressed following conidial anastomosis tube fusion in a fungal plant pathogen. PLoS One 7:e31175.

Jackson, R. W., Vinatzer, B., Arnold, D. L., Dorus, S., and Murillo, J. 2011. The influence of the accessory genome on bacterial pathogen evolution. Mob. Genet. Elements 1:55-65.

Johnson, R. D., Johnson, L., Itoh, Y., Kodama, M., Otani, H., and Kohmoto, K. 2000. Cloning and characterization of a cyclic peptide synthetase gene from Alternaria alternata apple pathotype whose product is involved in AM-toxin synthesis and pathogenicity. Mol. Plant-Microbe Interact 13:742-753.

Jones, J. D. G., and Dangl, J. L. 2006. The plant immune system. Nature 444:323-329.

Jones, R. N., Viegas, W., and Houben, A. 2008. A century of B chromosomes in plants: So what? Ann. Bot. 101:767-775.

Jones, R. W., Canada, S., and Wang, H. 1998. Highly variable minichromosomes and highly conserved endoglucanase genes in the phytopathogenic fungus Macrophomina phaseolina. Can. J. Bot. 76:694-698.

Jurgenson, J. E., Zeller, K. A., and Leslie, J. F. 2002. Expanded genetic map of Gibberella moniliformis (Fusarium verticillioides). Appl. Environ. Microbiol. 68:1972-1979.

Kellner, R., Bhattacharyya, A., Poppe, S., Hsu, T. Y., Brem, R. B., and Stukenbrock, E. H. 2014. Expression profiling of the wheat pathogen Zymoseptoria tritici reveals genomic patterns of transcription and hostspecific regulatory programs. Genome Biol. Evol. 6:1353-1365.
King, R., Urban, M., Hammond-Kosack, M. C., Hassani-Pak, K., and Hammond-Kosack, K. E. 2015. The completed genome sequence of the pathogenic ascomycete fungus Fusarium graminearum. BMC Genomics 16:544.

Klosterman, S. J., Subbarao, K. V., Kang, S., Veronese, P., Gold, S. E., Thomma, B. P., Chen, Z., Henrissat, B., Lee, Y.-H., Park, J., GarciaPedrajas, M. D., Barbara, D. J., Anchieta, A., de Jonge, R., Santhanam, P., Maruthachalam, K., Atallah, Z., Amyotte, S. G., Paz, Z., Inderbitzin, P., Hayes, R. J., Heiman, D. I., Young, S., Zeng, Q., Engels, R., Galagan, J., Cuomo, C. A., Dobinson, K. F., and Ma, L. J. 2011. Comparative genomics yields insights into niche adaptation of plant vascular wilt pathogens. PLoS Pathog. 7:e1002137.

Kodama, M., Rose, M. S., Yang, G., Yun, S. H., Yoder, O. C., and Turgeon, B. G. 1999. The translocation-associated tox1 locus of Cochliobolus heterostrophus is two genetic elements on two different chromosomes. Genetics 151:585-596.

Leclair, S., Ansan-Melayah, D., Rouxel, T., and Balesdent, M. 1996. Meiotic behaviour of the minichromosome in the phytopathogenic ascomycete Leptosphaeria maculans. Curr. Genet. 30:541-548.

Lewis, Z. A., Honda, S., Khlafallah, T. K., Jeffress, J. K., Freitag, M., Mohn, F., Schübeler, D., and Selker, E. U. 2009. Relics of repeat-induced point mutation direct heterochromatin formation in Neurospora crassa. Genome Res. 19:427-437.

Luo, C.-X., Yin, L.-F., Ohtaka, K., and Kusaba, M. 2007. The 1.6Mb chromosome carrying the avirulence gene AvrPik in Magnaporthe oryzae isolate $84 \mathrm{R}-62 \mathrm{~B}$ is a chimera containing chromosome 1 sequences. Mycol. Res. 111:232-239.

Ma, L.-J., van der Does, H. C., Borkovich, K. A., Coleman, J. J., Daboussi, M.-J., Di Pietro, A., Dufresne, M., Freitag, M., Grabherr, M., Henrissat, B., Houterman, P. M., Kang, S., Shim, W. B., Woloshuk, C., Xie, X., Xu, J. R., Antoniw, J., Baker, S. E., Bluhm, B. H., Breakspear, A., Brown, D. W., Butchko, R. A., Chapman, S., Coulson, R., Coutinho, P. M., Danchin, E. G., Diener, A., Gale, L. R., Gardiner, D. M., Goff, S., Hammond-Kosack, K. E., Hilburn, K., Hua-Van, A., Jonkers, W., Kazan, K., Kodira, C. D., Koehrsen, M., Kumar, L., Lee, Y. H., Li, L., Manners, J. M., Miranda-Saavedra, D., Mukherjee, M., Park, G., Park, J., Park, S. Y., Proctor, R. H., Regev, A., Ruiz-Roldan, M. C., Sain, D., Sakthikumar, S., Sykes, S., Schwartz, D. C., Turgeon, B. G., Wapinski, I., Yoder, O., Young, S., Zeng, Q., Zhou, S., Galagan, J., Cuomo, C. A., Kistler, H. C., and Rep, M. 2010. Comparative genomics reveals mobile pathogenicity chromosomes in Fusarium. Nature 464:367-373.

Mahmoud, A. M., and Taga, M. 2012. Cytological karyotyping and characterization of a $410 \mathrm{~kb}$ minichromosome in Nectria haematococca MPI. Mycologia 4:845-856.

Makunin, A. I., Dementyeva, P. V., Graphodatsky, A. S., Volobouev, V. T., Kukekova, A. V., and Trifonov, V. A. 2014. Genes on B chromosomes of vertebrates. Mol. Cytogenet. 7:99.

Manners, J. M., and He, C. 2011. Slow-growing heterokaryons as potential intermediates in supernumerary chromosome transfer between biotypes of Colletotrichum gloeosporioides. Mycol. Prog. 10:383-388.

Masunaka, A., Ohtani, K., Peever, T. L., Timmer, L. W., Tsuge, T., Yamamoto, M., Yamamoto, H., and Akimitsu, K. 2005. An isolate of Alternaria alternata that is pathogenic to both tangerines and rough lemon and produces two host-selective toxins, ACT- and ACR-toxins. Phytopathology 95:241-247.

McClintock, B. 1941. The stability of broken ends of chromosomes in Zea mays. Genetics 26:234-282.

McDonald, M.C., McGinness, L., Hane, J.K., Williams, A.H., Milgate, A., and Solomon, P.S. 2016. Utilizing gene tree variation to identify candidate effector genes in Zymoseptoria tritici. Genes Genom. Genet. 6: 779-791.

Mehrabi, R., Bahkali, A. H., Abd-Elsalam, K. A., Moslem, M., Ben M'barek, S., Gohari, A. M., Jashni, M. K., Stergiopoulos, I., Kema, G. H., and de Wit, P. J. 2011. Horizontal gene and chromosome transfer in plant pathogenic fungi affecting host range. FEMS Microbiol. Rev. 35:542-554.

Mehrabi, R., Taga, M., and Kema, G. H. J. 2007. Electrophoretic and cytological karyotyping of the foliar wheat pathogen Mycosphaerella graminicola reveals many chromosomes with a large size range. Mycologia 99:868-876.

Miao, V. P., Covert, S. F., and VanEtten, H. D. 1991. A fungal gene for antibiotic resistance on a dispensable ("B") chromosome. Science 254: 1773-1776.

Milgroom, M. G., Jiménez-Gasco, M. M., Olivares García, C., Drott, M. T., and Jiménez-Díaz, R. M. 2014. Recombination between clonal lineages of the asexual fungus Verticillium dahliae detected by genotyping by sequencing. PLoS One 9:e106740.

Miyamoto, Y., Masunaka, A., Tsuge, T., Yamamoto, M., Ohtani, K., Fukumoto, T., Gomi, K., Peever, T. L., and Akimitsu, K. 2008. 
Functional analysis of a multicopy host-selective ACT-toxin biosynthesis gene in the tangerine pathotype of Alternaria alternata using RNA silencing. Mol. Plant-Microbe Interact 21:1591-1599.

O'Connell, R. J., Thon, M. R., Hacquard, S., Amyotte, S. G., Kleemann, J., Torres, M. F., Damm, U., Buiate, E. A., Epstein, L., Alkan, N., Altmüller, J., Alvarado-Balderrama, L., Bauser, C. A., Becker, C., Birren, B. W., Chen, Z., Choi, J., Crouch, J. A., Duvick, J. P., Farman, M. A., Gan, P., Heiman, D., Henrissat, B., Howard, R. J., Kabbage, M., Koch, C., Kracher, B., Kubo, Y., Law, A. D., Lebrun, M. H., Lee, Y. H., Miyara, I., Moore, N., Neumann, U., Nordström, K., Panaccione, D. G., Panstruga, R., Place, M., Proctor, R. H., Prusky, D., Rech, G., Reinhardt, R., Rollins, J. A., Rounsley, S., Schardl, C. L., Schwartz, D. C., Shenoy, N., Shirasu, K., Sikhakolli, U. R., Stüber, K., Sukno, S. A., Sweigard, J. A., Takano, Y., Takahara, H., Trail, F., van der Does, H. C., Voll, L. M., Will, I., Young, S., Zeng, Q., Zhang, J., Zhou, S., Dickman, M. B., Schulze-Lefert, P., Ver Loren van Themaat, E., Ma, L. J., and Vaillancourt, L. J. 2012. Lifestyle transitions in plant pathogenic Colletotrichum fungi deciphered by genome and transcriptome analyses. Nat. Genet. 44:1060-1065.

O'Garro, L., and Clarkson, J. 1992. Variation for pathogenicity on tomato among parasexual recombinants of Verticillium dahliae. Plant Pathol. 41:141-147.

O’Sullivan, D., Tosi, P., Creusot, F., Cooke, B. M., Phan, T.-H., Dron, M., and Langin, T. 1998. Variation in genome organization of the plant pathogenic fungus Colletotrichum lindemuthianum. Curr. Genet. 33: 291-298.

Ohm, R. A., Feau, N., Henrissat, B., Schoch, C. L., Horwitz, B. A., Barry, K. W., Condon, B. J., Copeland, A. C., Dhillon, B., Glaser, F., Hesse, C. N., Kosti, I., LaButti, K., Lindquist, E. A., Lucas, S., Salamov, A. A., Bradshaw, R. E., Ciuffetti, L., Hamelin, R. C., Kema, G. H., Lawrence, C., Scott, J. A., Spatafora, J. W., Turgeon, B. G., de Wit, P. J., Zhong, S., Goodwin, S. B., and Grigoriev, I. V. 2012. Diverse lifestyles and strategies of plant pathogenesis encoded in the genomes of eighteen Dothideomycetes fungi. PLoS Pathog. 8:e1003037.

Oliver, R. 2012. Genomic tillage and the harvest of fungal phytopathogens. New Phytol. 196:1015-1023.

Pantou, M. P., and Typas, M. A. 2005. Electrophoretic karyotype and gene mapping of the vascular wilt fungus Verticillium dahliae. FEMS Microbiol. Lett. 245:213-220.

Paoletti, M. 2016. Vegetative incompatibility in fungi: From recognition to cell death, whatever does the trick. Fungal Biol. Rev. 30:152-162.

Pitkin, J. W., Nikolskaya, A., Ahn, J.-H., and Walton, J. D. 2000. Reduced virulence caused by meiotic instability of the TOX2 chromosome of the maize pathogen Cochliobolus carbonum. Mol. Plant-Microbe Interact. 13:80-87.

Plissonneau, C., Stürchler, A., and Croll, D. 2016. The Evolution of orphan regions in genomes of a fungal pathogen of wheat. MBio 7:e01231-16.

Plummer, K. M., and Howlett, B. J. 1995. Inheritance of chromosomal length polymorphisms in the ascomycete Leptosphaeria maculans. Mol. Gen. Genet. 247:416-422.

Raffaele, S., and Kamoun, S. 2012. Genome evolution in filamentous plant pathogens: Why bigger can be better. Nat. Rev. Microbiol. 10:417-430.

Roca, M. G., Davide, L. C., Mendes-Costa, M. C., and Wheals, A. 2003. Conidial anastomosis tubes in Colletotrichum. Fungal Genet. Biol. 40: 138-145.

Rouxel, T., Grandaubert, J., Hane, J. K., Hoede, C., van de Wouw, A. P., Couloux, A., Dominguez, V., Anthouard, V., Bally, P., Bourras, S., Cozijnsen, A. J., Ciuffetti, L. M., Degrave, A., Dilmaghani, A., Duret, L., Fudal, I., Goodwin, S. B., Gout, L., Glaser, N., Linglin, J., Kema, G. H., Lapalu, N., Lawrence, C. B., May, K., Meyer, M., Ollivier, B., Poulain, J., Schoch, C. L., Simon, A., Spatafora, J. W., Stachowiak, A., Turgeon, B. G., Tyler, B. M., Vincent, D., Weissenbach, J., Amselem, J., Quesneville, H., Oliver, R. P., Wincker, P., Balesdent, M. H., and Howlett, B. J. 2011. Effector diversification within compartments of the Leptosphaeria maculans genome affected by Repeat-Induced Point mutations. Nat. Commun. 2:202.

Ruswandi, S., Kitani, K., Akimitsu, K., Tsuge, T., Shiraishi, T., and Yamamoto, M. 2005. Structural analysis of cosmid clone pcAFT-2 carrying AFT10-1 encoding an acyl-CoA dehydrogenase involved in AFtoxin production in the strawberry pathotype of Alternaria alternata. J. Gen. Plant Pathol. 71:107-116.

Schmidt, S. M., Houterman, P. M., Schreiver, I., Ma, L., Amyotte, S., Chellappan, B., Boeren, S., Takken, F. L., and Rep, M. 2013. MITEs in the promoters of effector genes allow prediction of novel virulence genes in Fusarium oxysporum. BMC Genomics 14:119.

Schotanus, K., Soyer, J. L., Connolly, L. R., Grandaubert, J., Happel, P., Smith, K. M., Freitag, M., and Stukenbrock, E. H. 2015. Histone modifications rather than the novel regional centromeres of Zymoseptoria tritici distinguish core and accessory chromosomes. Epigenetics Chromatin 8:41.
Singer, M., and Selker, E. 1995. Genetic and epigenetic inactivation of repetitive sequences in Neurospora crassa: RIP, DNA methylation, and quelling. Pages 165-177 in: Gene Silencing in Higher Plants and Related Phenomena in other Eukaryotes $>$ N. S. Iacobellis. A. Collmer, S. W. Hutcheson, J. W. Mansfield, C. E. Morris, J. Murillo, N. W. Schaad, D. E. Stead, G. Surico, and M. Ullrich, eds. Kluwer Academic Springers, Dordrecht, The Netherlands.

Soyer, J. L., El Ghalid, M., Glaser, N., Ollivier, B., Linglin, J., Grandaubert, J., Balesdent, M.-H., Connolly, L. R., Freitag, M., Rouxel, T., and Fudal, I. 2014. Epigenetic control of effector gene expression in the plant pathogenic fungus Leptosphaeria maculans. PLoS Genet. 10:e1004227.

Soyer, J. L., Möller, M., Schotanus, K., Connolly, L. R., Galazka, J. M., Freitag, M., and Stukenbrock, E. H. 2015. Chromatin analyses of Zymoseptoria tritici: Methods for chromatin immunoprecipitation followed by highthroughput sequencing (ChIP-seq). Fungal Genet. Biol. 79:63-70.

Stewart, E. L., Croll, D., Lendenmann, M. H., Sanchez-Vallet, A., Hartmann, F. E., Palma-Guerrero, J., Ma, X., and McDonald, B. A. 2018. Quantitative trait locus mapping reveals complex genetic architecture of quantitative virulence in the wheat pathogen Zymoseptoria tritici. Mol. Plant Pathol. 19:201-216.

Strom, N. B., and Bushley, K. E. 2016. Two genomes are better than one: History, genetics, and biotechnological applications of fungal heterokaryons. Fungal Biol. Biotechnol. 3:4.

Stukenbrock, E. H., Quaedvlieg, W., Javan-Nikhah, M., Zala, M., Crous, P. W., and McDonald, B. A. 2012. Zymoseptoria ardabiliae and Z. pseudotritici, two progenitor species of the septoria tritici leaf blotch fungus Z. tritici (synonym: Mycosphaerella graminicola). Mycologia 104:1397-1407.

Syme, R.A., Hane, J.K., Friesen, T.L., and Oliver, R.P. 2013. Resequencing and comparative genomics of Stagonospora nodorum: Sectional gene absence and effector discovery. Genes Genom. Genet. 3:959-969.

Taga, M., Murata, M., and VanEtten, H. D. 1999. Visualization of a conditionally dispensable chromosome in the filamentous ascomycete Nectria haematococca by fluorescence in situ hybridization. Fungal Genet. Biol. 26:169-177.

Talbot, N. J., Salch, Y. P., Ma, M., and Hamer, J. E. 1993. Karyotypic variation within clonal lineages of the rice blast fungus, Magnaporthe grisea. Appl. Environ. Microbiol. 59:585-593.

Tamaru, H., and Selker, E. U. 2003. Synthesis of signals for de novo DNA methylation in Neurospora crassa. Mol. Cell. Biol. 23:2379-2394.

Tan, K.-C., Waters, O. D., Rybak, K., Antoni, E., Furuki, E., and Oliver, R. P. 2014. Sensitivity to three Parastagonospora nodorum necrotrophic effectors in current Australian wheat cultivars and the presence of further fungal effectors. Crop Pasture Sci. 65:150-158.

Tanaka, A., and Tsuge, T. 2000. Structural and functional complexity of the genomic region controlling AK-toxin biosynthesis and pathogenicity in the Japanese pear pathotype of Alternaria alternata. Mol. Plant-Microbe Interact 13:975-986.

Temporini, E. D., and VanEtten, H. D. 2002. Distribution of the pea pathogenicity $(P E P)$ genes in the fungus Nectria haematococca mating population VI. Curr. Genet. 41:107-114.

Testa, A. C., Oliver, R. P., and Hane, J. K. 2016. OcculterCut: A comprehensive survey of AT-rich regions in fungal genomes. Genome Biol. Evol. 8:2044-2064.

Tsuge, T., Harimoto, Y., Akimitsu, K., Ohtani, K., Kodama, M., Akagi, Y., Egusa, M., Yamamoto, M., and Otani, H. 2013. Host-selective toxins produced by the plant pathogenic fungus Alternaria alternata. FEMS Microbiol. Rev. 37:44-66.

Tsuge, T., Harimoto, Y., Hanada, K., Akagi, Y., Kodama, M., Akimitsu, K., and Yamamoto, M. 2016. Evolution of pathogenicity controlled by small, dispensable chromosomes in Alternaria alternata pathogens. Physiol. Mol. Plant Pathol. 95:27-31.

Tzeng, T.-H., Lyngholm, L. K., Ford, C. F., and Bronson, C. R. 1992. A restriction fragment length polymorphism map and electrophoretic karyotype of the fungal maize pathogen Cochliobolus heterostrophus. Genetics 130:81-96.

van Dam, P., Fokkens, L., Schmidt, S. M., Linmans, J. H., Kistler, H. C., Ma, L. J., and Rep, M. 2016. Effector profiles distinguish formae speciales of Fusarium oxysporum. Environ. Microbiol. 18:4087-4102.

Van de Wouw, A. P., Cozijnsen, A. J., Hane, J. K., Brunner, P. C., McDonald, B. A., Oliver, R. P., and Howlett, B. J. 2010. Evolution of linked avirulence effectors in Leptosphaeria maculans is affected by genomic environment and exposure to resistance genes in host plants. PLoS Pathog. 6:e1001180.

van der Does, H. C., Fokkens, L., Yang, A., Schmidt, S. M., Langereis, L., Lukasiewicz, J. M., Hughes, T. R., and Rep, M. 2016. Transcription Factors Encoded on Core and Accessory Chromosomes of Fusarium 
oxysporum Induce Expression of Effector Genes. PLoS Genet. 12: e1006401.

Van Kan, J. A. L., Stassen, J. H. M., Mosbach, A., Van Der Lee, T. A. J., Faino, L., Farmer, A. D., Papasotiriou, D. G., Zhou, S., Seidl, M. F., Cottam, E., Edel, D., Hahn, M., Schwartz, D. C., Dietrich, R. A., Widdison, S., and Scalliet, G. 2017. A gapless genome sequence of the fungus Botrytis cinerea. Mol. Plant Pathol. 18:75-89.

Vanheule, A., Audenaert, K., Warris, S., van de Geest, H., Schijlen, E., Höfte, M., De Saeger, S., Haesaert, G., Waalwijk, C., and van der Lee, T. 2016. Living apart together: Crosstalk between the core and supernumerary genomes in a fungal plant pathogen. BMC Genomics 17:670.

Vlaardingerbroek, I., Beerens, B., Rose, L., Fokkens, L., Cornelissen, B. J., and Rep, M. 2016a. Exchange of core chromosomes and horizontal transfer of lineage-specific chromosomes in Fusarium oxysporum. Environ. Microbiol. 18:3702-3713.

Vlaardingerbroek, I., Beerens, B., Schmidt, S. M., Cornelissen, B. J., and Rep, M. 2016b. Dispensable chromosomes in Fusarium oxysporum f. sp. lycopersici. Mol. Plant Pathol. 17:1455-1466.

Wang, C., Skrobek, A., and Butt, T. M. 2003. Concurrence of losing a chromosome and the ability to produce destruxins in a mutant of Metarhizium anisopliae. FEMS Microbiol. Lett. 226:373-378.

Ware, S. B. 2006. Aspects of sexual reproduction in Mycosphaerella species on wheat and barley: genetic studies on specificity, mapping, and fungicide resistance. Dissertation. Wageningen University, Wangeningen, The Netherlands.
Wasmann, C. C., and VanEtten, H. D. 1996. Transformation-mediated chromosome loss and disruption of a gene for pisatin demethylase decrease the virulence of Nectria haematococca on pea. Mol. PlantMicrobe Interact. 9:793-803.

Williams, A. H., Sharma, M., Thatcher, L. F., Azam, S., Hane, J. K., Sperschneider, J., Kidd, B. N., Anderson, J. P., Ghosh, R., Garg, G., Lichtenzveig, J., Kistler, H. C., Shea, T., Young, S., Buck, S. A., Kamphuis, L. G., Saxena, R., Pande, S., Ma, L. J., Varshney, R. K., and Singh, K. B. 2016. Comparative genomics and prediction of conditionally dispensable sequences in legume-infecting Fusarium oxysporum formae speciales facilitates identification of candidate effectors. BMC Genomics 17:191.

Wisecaver, J. H., and Rokas, A. 2015. Fungal metabolic gene clusterscaravans traveling across genomes and environments. Front. Microbiol. 6:161.

Wittenberg, A. H. J., van der Lee, T. A. J., Ben M'Barek, S., Ware, S. B., Goodwin, S. B., Kilian, A., Visser, R. G. F., Kema,G. H. J., and Schouten, H. J. 2009. Meiosis drives extraordinary genome plasticity in the haploid fungal plant pathogen Mycosphaerella graminicola. PLoS One 4:e5863.

Xue, M., Yang, J., Li, Z., Hu, S., Yao, N., Dean, R. A., Zhao, W., Shen, M., Zhang, H., Li, C., Liu, L., Cao, L., Xu, X., Xing, Y., Hsiang, T., Zhang, Z., Xu, J. R., and Peng, Y. L. 2012. Comparative analysis of the genomes of two field isolates of the rice blast fungus Magnaporthe oryzae. PLoS Genet. 8:e1002869.

Zolan, M. E. 1995. Chromosome-length polymorphism in fungi. Microbiol. Rev. 59:686-698. 